\title{
A new species of the genus Arhynchite (Annelida, Echiura) from sandy flats of Japan, previously referred to as Thalassema owstoni Ikeda, 1904
}

\author{
Masaatsu Tanaka ${ }^{1, \dagger}$, Teruaki Nishikawa ${ }^{1, \neq}$ \\ I Department of Biology, Faculty of Science, Toho University, 2-2-1 Miyama, Funabashi, Chiba 274-8510, Japan \\ † urn:lsid:zoobank.org:author:E31DD0A5-9C0C-4A2A-A963-81965578B726 \\ †urn:lsid:zoobank.org:author:4E07D37B-5EA5-48CE-BCOC-B62DBB844DB7 \\ Corresponding author: Masaatsu Tanaka (echiura.sipuncula@gmail.com)
}

Academic editor: Chris Glasby | Received 3 May 2013 | Accepted 20 June 2013 | Published 24 June 2013

urn:lsid:zoobank.org:pub:90C48CD4-C195-4C65-A04F-7FODEOF18614

Citation: Tanaka M, Nishikawa T (2013) A new species of the genus Arhynchite (Annelida, Echiura) from sandy flats of Japan, previously referred to as Thalassema owstoni Ikeda, 1904. ZooKeys 312: 13-21. doi: 10.3897/zookeys.312.5456

\begin{abstract}
A new echiuran, Arhynchite hayaoi sp. n., is described from newly collected specimens from sandy flats of the Seto Inland Sea, Japan, together with many museum specimens, including those once identified as Thalassema owstoni Ikeda, 1904 or $A$. arhynchite (Ikeda, 1924). The new species is clearly distinguishable from its congeners by the smooth margin of gonostomal lips and lack of rectal caecum. Brief references are also made to the morphological distinction between the new species and T. owstoni, originally described from the deep bottom on the Japanese Pacific coast.
\end{abstract}

\section{Keywords}

Annelida, Echiura, new species, Arhynchite hayaoi, Thalassema owstoni, sandy flat, Seto Inland Sea

\section{Introduction}

Echiurans are a small group of marine coelomates, previously classified as a distinct phylum, but now often included in the Phylum Annelida on the basis of recent molecular phylogenetic analyses (McHugh 1997, Bleidorn et al. 2003, Struck et al. 2007, 2011). 
The Japanese echiuran fauna was extensively studied by Prof. Iwaji Ikeda and Dr Hayao Sato in the early and middle parts of the last century, respectively, resulting in our present understanding of the known fauna consisting of ca 20 species (Nishikawa 1992). However, many taxonomic problems remain unsolved, one of which concerns an echiuran called "kouju" in Japanese (probably meaning "good bait"). This echiuran was once abundant and collected in great numbers from intertidal or subtidal sandy bottoms for fish bait in the Seto Inland Sea, Japan (Mori et al. 1932, Ishikawa 1938); however, its density has lately declined too greatly for such use (Nishikawa 2007, 2012, Saito et al. 2011).

The echiuran in the present study was first identified as Thalassema mucosum (currently accepted as Anelassorhynchus mucosus (Ikeda, 1904)) by Mori et al. (1932). It was soon referred to by Sato (1934), one of the above-mentioned specialists, as T. owstoni Ikeda, 1904, established for a damaged deep-water Japanese specimen, after his own examination of specimens newly collected from Onomichi Bay in the Seto Inland Sea. Although Sato's (1934) description lacked any information on their internal morphology or the reason for his corrected identification, his taxonomy has been followed by subsequent authors (Sato 1935, 1939, Ishikawa 1938, Stephen and Edmonds 1972, Nishikawa 1992, 2012).

We have compared echiurans newly collected from a sandy flat near Onomichi Bay with the specimens deposited in the Tohoku University Museum (TUM), collected from the bay in 1931 and labeled as "Thalassema owstoni Ikeda" and "kouji" (probably equivalent to "kouju"), probably by Sato, who then belonged to the Tohoku Imperial University, the predecessor of Tohoku University. We found the old and new specimens to be very similar. Further, we found a significant difference between the specimens and the description of T. owstoni Ikeda, 1904, although we attempted to examine its holotype and collect new specimens from the type locality, we have so far been unsuccessful. Thus, we herein describe "kouju" as a new species of the genus Arhynchite Satô, 1937.

\section{Materials and methods}

We collected new specimens from a sandy flat, named Hachi-no-higata, at the mouth of the Kamogawa River, Takehara, Hiroshima Prefecture, Japan in 2011. The specimens were relaxed with menthol, and minute pieces of proboscis were taken from the holotype and two paratypes and fixed with pure ethanol for future molecular analyses; all remaining material was fixed in 10\% seawater formalin and then stored in $70 \%$ ethanol. Further materials have been retained at our Laboratory of Taxonomy, Toho University (LTTU), the Department of Zoology, University Museum, University of Tokyo (UMUTZ), or TUM. The type series, as well as the two non-type ones, are deposited in the National Museum of Nature and Science, Tsukuba, Japan (NSMT).

Observations, dissections, and drawings were made under a stereoscopic microscope. Trunk length (TL) and proboscis length (PL) were measured. General terminology was based on Stephen and Edmonds (1972) and Nishikawa (2004). 


\section{Taxonomy}

\section{Arbynchite hayaoi sp. n.}

urn:lsid:zoobank.org:act:598901D0-6F77-4F4B-AA50-343FEAD4F9E5

http://species-id.net/wiki/Arhynchite_hayaoi

New Japanese name: Setouchi-dochikuchi-yumushi

Figs 1, 2

Thalassema owstoni: Sato 1934, p. 249, figs 2 and 3; Satô 1939, p. 354.

Arhynchite arhynchite: Nishikawa 2001, pp. 137-138.

Specimens examined. Holotype: NSMT-Ec 100, mature male, TL 25 mm, PL > 5 $\mathrm{mm}$ (proboscis damaged), Hachi-no-higata sandy flat at the mouth of the Kamogawa River, Hiroshima Pref., Japan $\left(34^{\circ} 19.42^{\prime} \mathrm{N}, 132^{\circ} 53.88^{\prime} \mathrm{E}\right)$, May 18, 2011, collected by M. Tanaka and T. Nishikawa. Paratypes: NSMT-Ec 101-105, 3 males + 2 females, TL 28-40 mm, PL $6 \mathrm{~mm}$, collection data as for the holotype. Non-type specimens: TUM Echiurida 2-11, labeled as "Thalassema owstoni Ikeda" probably by H. Sato, 8 males +6 females +1 specimen of unknown sex, TL 29-73 mm, proboscis absent,

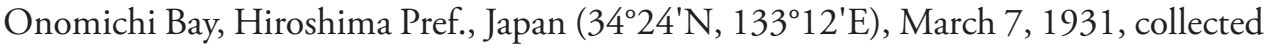
by Takashi Gamo; TUM Echiurida 1-5, labeled as "Thalassema owstoni Ikeda" and "kouji" probably by H. Sato, 2 males + 3 females + 1 of unknown sex, TL 31-62 mm,

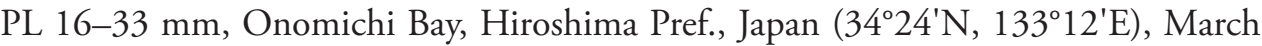
7, 1931, by Takashi Gamo; NSMT-Ec 106, 1 of unknown sex, TL 28 mm, proboscis absent, intertidal sandy flat at the mouth of the Kamogawa River, Hiroshima Pref., Japan $\left(34^{\circ} 19.42^{\prime} \mathrm{N}, 132^{\circ} 53.88^{\prime} \mathrm{E}\right)$, July 8, 2006, by Masanori Sato; NSMT-Ec 107 , 1 of unknown sex, TL $33 \mathrm{~mm}$, proboscis absent, intertidal sandy to muddy flat on Ikarise Islet, located in a channel of Lake Hamana, Shizuoka Pref., Japan $\left(34^{\circ} 41.08^{\prime} \mathrm{N}\right.$, $137^{\circ} 35.98^{\prime}$ E), April 19, 2003, by Shoichi Kimura; UMUTZ-Ecur-2, 1 of unknown sex, TL $55 \mathrm{~mm}$, proboscis absent, above low-water mark, Tomono-ura, Hiroshima Pref., Japan $\left(34^{\circ} 22^{\prime} \mathrm{N}, 133^{\circ} 23^{\prime} \mathrm{E}\right)$, July 1882 , by I. Ikeda, reported as $A$. arhynchite (Ikeda) by Nishikawa (2001); UMUTZ-Ecur-10, 1 of unknown sex, TL $38 \mathrm{~mm}$, proboscis absent, Misaki, Sagami Bay, Kanagawa Pref., Japan (3509’N, 139³6’E), collection data unknown, reported as $A$. arhynchite by Nishikawa (2001). Specimens for comparison: $A$. arhynchite; LTTU-Y009, 1 female +3 of unknown sex, TL 42-74 mm, off Abashiri ,Hokkaido, Japan, 7-12 m depth, September 17, 2001, collected by Yasuhiro Kuwahara.

Diagnosis. Trunk up to $80 \mathrm{~mm}$ long in preserved specimens. Leaf-like gonostomal lips with smooth margins. Neurointestinal vessel unbifurcated. Ring vessel absent. Rectal caecum absent. Anal vesicles fastened basally to the trunk wall by mesenteries.

Description. In life, trunk colored pinkish yellow and proboscis pale yellow (Fig. 1). Coloration fading to pale white or beige after fixation with formalin.

In preserved specimens, TL ranging from 25 to $73 \mathrm{~mm}(\mathrm{n}=28)$ and PL ranging from 6 to $33 \mathrm{~mm}(\mathrm{n}=8)$. Proboscis, often detached from trunk, elongated and slight- 


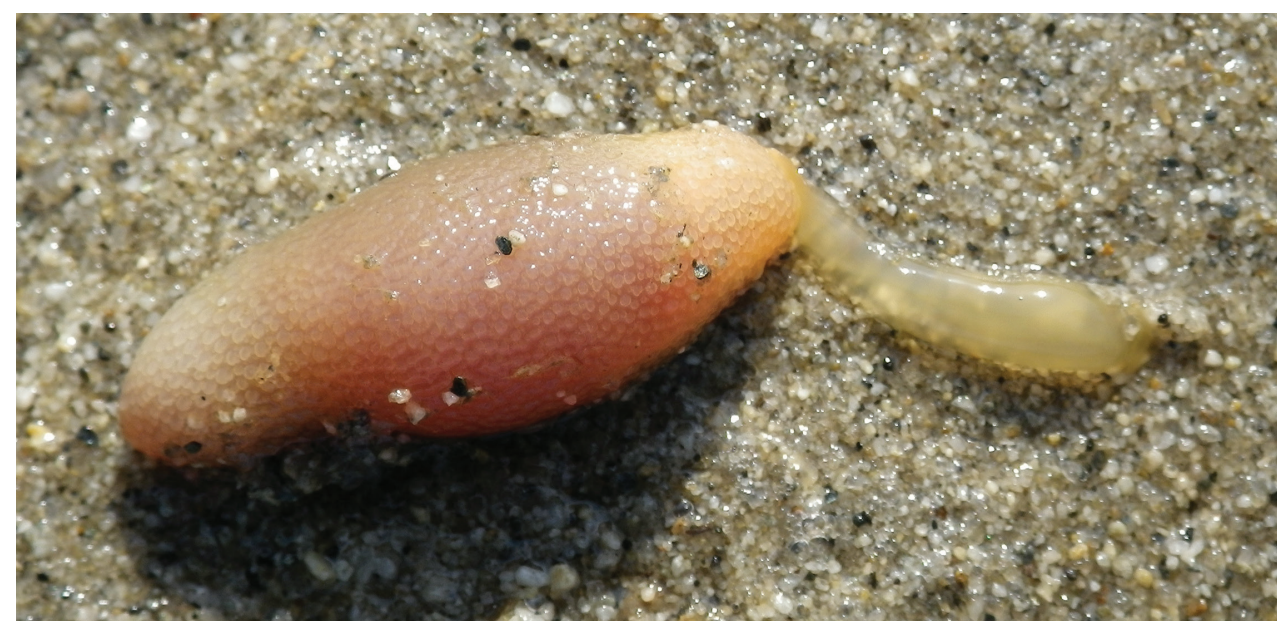

Figure I. Arhynchite hayaoi sp. n., found at the type locality, with the proboscis extending toward the right.

ly expanded at its extremity, with its proximal end forming small lower cup around mouth. Trunk wall thickened and covered with numerous distinct papillae, especially prominent (up to $1 \mathrm{~mm}$ ) at both extremities. Trunk musculature consisting of outermost circular, middle longitudinal, and innermost oblique layers, all of which continuous throughout.

Paired ventral setae of usual form, with strong interbasal muscle (Fig. 2A), but only very rarely single seta without interbasal muscle in 2 of 6 non-type specimens in TUM Echiurida 1-5.

Paired gonoducts situated slightly behind ventral setae (Fig. 2A). Gonostomes situated proximally, each with leaf-like gonostomal lip with smooth margin (Fig. 2B); lip plicated marginally, probably due to fixation in many non-type specimens (TUM Echiurida 1-5, 2-11).

Long and convoluted alimentary canal, filled with sand grains and elliptical fecal pellets, ca $2 \mathrm{~mm}$ in long axis (Fig. 2A, C). Anterior part of alimentary canal, so-called foregut, divided into pharynx, esophagus, gizzard, and crop (Fig. 2A). Intestine following foregut fastened to trunk wall with numerous thread-like mesenteries and divided into pre-siphonal, siphonal, and post-siphonal parts (Fig. 2A, C). Pre- and post-siphonal parts having a ciliated groove; elongated pre-siphonal part about twice as long as TL (Fig. 2A). Rectal caecum absent (Fig. 2C).

Vascular system composed of dorsal, neurointestinal, and ventral vessels, without ring vessel (Fig. 2A). Dorsal vessel attached to entire length of crop (Fig. 2A). Ventral vessel running along almost entire length of ventral nerve cord and terminating at posterior end of post-siphonal intestine near anus (Fig. 2A, C). Neurointestinal vessel, although injured in holotype, issuing from ventral vessel slightly behind gonostomal level and terminating at anterior end of intestine without bifurcation (Fig. 2A). In 6 non-type specimens (5 in TUM Echiurida 2-11 and 1 in TUM Echiurida 1-5), ventral vessel issuing additional branch forward at ventral origin of neurointestinal vessel, 


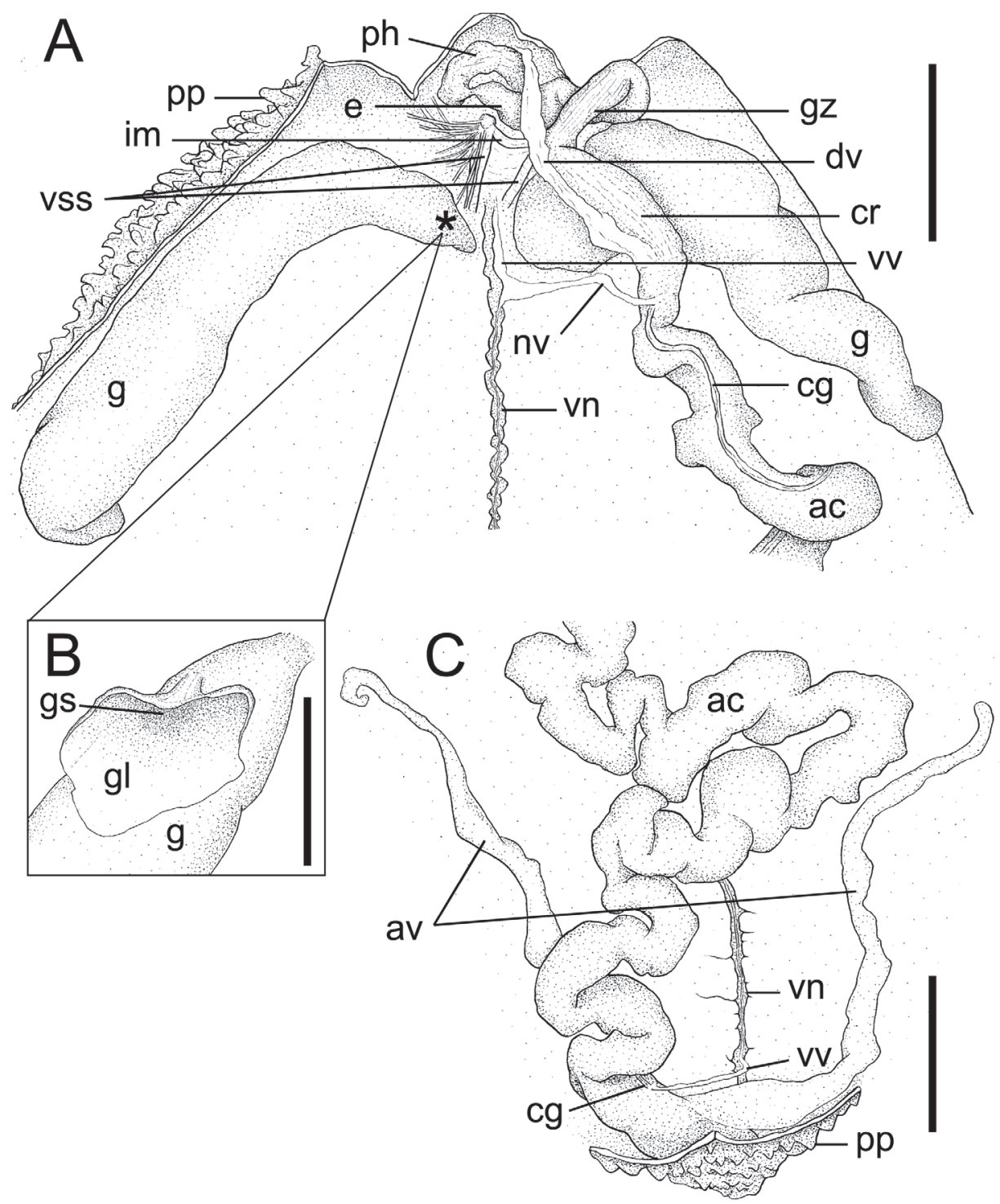

Figure 2. Arhynchite hayaoi sp. n., paratype (NSMT-Ec 104). A internal morphology of the anterior end of the trunk, dorsal view; an asterisk indicates the position of the gonostome $\mathbf{B}$ gonostome and gonostomal lip, magnified $\mathbf{C}$ internal morphology of the posterior end of the trunk, dorsal view. Abbreviations: ac alimentary canal; av anal vesicle; $\mathbf{c g}$ ciliated groove; $\mathbf{c r}$ crop; $\mathbf{d v}$ dorsal vessel; $\mathbf{e}$ esophagus; $\mathbf{g}$ gonoduct; gl gonostomal lip; gs gonostome; gz gizzard; im interbasal muscle; nv neurointestinal vessel; ph pharynx; pp papillae; vn ventral nerve cord; vss ventral setal sac; vv ventral vessel. Scales: A and C 5 mm; B $1 \mathrm{~mm}$.

with the branch terminally forming small loop around interbasal muscle. Further, in another non-type specimen of TUM Echiurida 1-5, origin of neurointestinal vessel shifted far forward, crossing interbasal muscle but without additional branches. 
Table I. A comparison of all known species referred to the genus Arbynchite.

\begin{tabular}{|c|c|c|c|c|c|c|c|}
\hline Species & $\begin{array}{l}\text { Rectal } \\
\text { caecum }\end{array}$ & $\begin{array}{l}\text { Ring } \\
\text { vessel }\end{array}$ & \begin{tabular}{|c|}
$\begin{array}{c}\text { Bifurcation of } \\
\text { neurointestinal } \\
\text { vessel }\end{array}$ \\
\end{tabular} & \begin{tabular}{|c|}
$\begin{array}{c}\text { Margin of } \\
\text { gonostomal } \\
\text { lip }\end{array}$ \\
\end{tabular} & $\begin{array}{c}\text { Mesenteries } \\
\text { mainly } \\
\text { fastened to }\end{array}$ & Type locality & Sources \\
\hline $\begin{array}{l}\text { Arhynchite } \\
\text { hayaoi sp. n. }\end{array}$ & absent & absent & absent & smooth & body wall & $\begin{array}{l}\text { Seto Inland } \\
\text { Sea, Japan }\end{array}$ & This study \\
\hline $\begin{array}{l}\text { Arhynchite } \\
\text { arhynchite }\end{array}$ & absent & absent & $\begin{array}{c}\text { barely } \\
\text { detectable }\end{array}$ & $\begin{array}{c}\text { with } \\
\text { digitiform } \\
\text { projections }\end{array}$ & body wall & $\begin{array}{c}\text { Probably } \\
\text { around } \\
\text { Hokkaido, } \\
\text { Japan }\end{array}$ & $\begin{array}{c}\text { Ikeda (1924), } \\
\text { Satô (1937), } \\
\text { This study }\end{array}$ \\
\hline $\begin{array}{l}\text { Arhynchite } \\
\text { californicus }\end{array}$ & absent & absent & absent & $\begin{array}{c}\text { with } \\
\text { digitiform } \\
\text { projections }\end{array}$ & body wall & $\begin{array}{c}\text { Monterey Bay, } \\
\text { California, } \\
\text { USA }\end{array}$ & Fisher (1949) \\
\hline $\begin{array}{c}\text { Arhynchite } \\
\text { hiscocki }\end{array}$ & absent & absent & absent & $\begin{array}{c}\text { with } \\
\text { digitiform } \\
\text { projections }\end{array}$ & intestine & $\begin{array}{l}\text { Dunwich, } \\
\text { Queensland, } \\
\text { Australia }\end{array}$ & $\begin{array}{c}\text { Edmonds } \\
(1960,1987)\end{array}$ \\
\hline $\begin{array}{l}\text { Arhynchite } \\
\text { inamoenus }\end{array}$ & absent & absent & absent & $\begin{array}{l}\text { with } \\
\text { irregular } \\
\text { serrations }\end{array}$ & unknown & $\begin{array}{c}\text { Monterey Bay, } \\
\text { California, } \\
\text { USA }\end{array}$ & Fisher (1946) \\
\hline $\begin{array}{l}\text { Arhynchite } \\
\text { pugettensis }\end{array}$ & absent & present & absent & $\begin{array}{l}\text { with } \\
\text { irregular } \\
\text { serrations }\end{array}$ & body wall & \begin{tabular}{|c|} 
Puget Sound, \\
Washington, \\
USA \\
\end{tabular} & Fisher (1949) \\
\hline $\begin{array}{c}\text { Arhynchite } \\
\text { paulensis }\end{array}$ & present & absent & unknown & $\begin{array}{l}\text { with } \\
\text { irregular } \\
\text { serrations }\end{array}$ & intestine & $\begin{array}{c}\text { Araça Beach, } \\
\text { Sáo Paulo, } \\
\text { Brazil }\end{array}$ & Amor (1971) \\
\hline $\begin{array}{c}\text { Arhynchite } \\
\text { rugosus }\end{array}$ & present & unknown & unknown & smooth & unknown & $\begin{array}{c}\text { Jiaozhou Bay, } \\
\text { Shandong, } \\
\text { China }\end{array}$ & $\begin{array}{c}\text { Chen and Yeh } \\
\text { (1958) }\end{array}$ \\
\hline
\end{tabular}

Paired simple anal vesicles, ca one-third of TL in holotype, while rarely attaining TL in other specimens, covered wholly with numerous microscopic ciliated funnels and fastened basally to trunk wall by some mesenteries (Fig. 2C).

Etymology. The specific name is dedicated to the late Dr Hayao Sato who made a significant contribution to the taxonomy of echiurans, sipunculans, and priapulids in Japan and adjacent waters.

Distribution. Hiroshima Pref. (Seto Inland Sea), Ikarise Islet at the entrance of Lake Hamana, and Misaki (Sagami Bay), Japan, intertidal to subtidal, sandy to muddy bottoms.

Remarks. Table 1 gives a comparison of all known species and the newly described species assigned to the genus Arhynchite. A. hayaoi sp. n. is distinguishable from $A$. arhynchite, the only congener recorded to date from Japanese coasts, by the absence of such digitiform projections or irregular serrations along the margin of the gonostomal lips as are present in A. californicus and A.pugettensis, respectively (Fisher 1949, pls. 30, 32 ), and by the complete lack of bifurcation in the neurointestinal vessel. 
Nishikawa (2001) recorded A. arhynchite from Sagami Bay and the Seto Inland Sea. Our detailed re-examination of these specimens revealed that they are assignable to $A$. hayaoi, instead of $A$. arhynchite. Thus, it is possible that $A$. hayao $i$ is widely distributed in the Seto Inland Sea and the Pacific coasts of Middle Japan, whereas $A$. arhynchite, with its type locality probably originating near Hokkaido (Ikeda 1924, Satô 1937), is restricted to cold northern waters.

\section{Discussion}

T. owstoni was established by Ikeda (1904, pp. 62-63, figs 18, 96-97) based solely on the holotype, dredged from 180 fathoms (ca $330 \mathrm{~m}$ ) deep in the Uraga Channel at the entrance of Tokyo Bay. Since then, no further specimens have been collected. According to the original description, "The specimen [= the holotype] is torn near the posterior end of the body" (p. 62), probably lacking the greater part of the alimentary canal, the anal vesicles, and the vascular system. Our efforts to locate the holotype of T. owstoni in order to gain more information have so far been unsuccessful. On the basis of the original description, however, this species is clearly distinguishable from $A$. hayao $i$ by the shape of the gonostomal lips (funnel-shaped in T. owstoni vs. leaf-like in A. hayaoi).

Thus, the taxonomic identity of T. owstoni remains unknown. Bock (1942) provisionally regarded this species as belonging to Maxmuelleria based on Ikeda's original description, following Wharton's key (1913, p. 261) that "Anal trees bear large funnels situated close together on long stalks." This taxonomic treatment, however, is not followed by subsequent authors (Stephen and Edmonds 1972, Saxena 1984, Biseswar 1988, Nishikawa 1992, 2012). Without new material or the rediscovery of the holotype, the identity of $T$. owstoni remains unresolved.

Thalassema fuscum Ikeda, 1904 is also similar to $A$. hayao in terms of living coloration (Ikeda 1904, p. 70 and fig. 21), the trunk surface densely covered with prominent papillae, and the occurrence of a single pair of gonoducts with the gonostomal lip expanded as a leaf. However, T. fuscum is distinguished from $A$. hayaoi by the existence of a conspicuous ring vessel and a bifurcated neurointestinal vessel, as well as by the absence of interbasal muscle. Our present understanding of the last feature comes from the fact that $T$. fuscum's original description (Ikeda 1904, pp. 69-70) lacks any information on the muscle, but the taxonomic key of all species mentioned in Ikeda's monograph (1904, p. 82) clearly shows "No interbasal muscle" for T. fuscum.

\section{Acknowledgements}

Our cordial thanks are due to Drs S. Sato (TUM) and R. Ueshima (UMUTZ) for loan of specimens with permission to dissect; $\mathrm{Mr} \mathrm{K}$. Okada for help in collecting specimens; Dr M. Sato (Kagoshima University), Messrs Y. Kuwahara (Abashiri Fisheries Research Institute) and S. Kimura (Mie University) for materials; Dr T. Kon (Toho University) 
for helpful discussions; a reviewer for helpful comments on the manuscript; and to Enago (www.enago.jp) for English language review. This study was partly supported by a Grant-in-Aid for Field Research from Faculty of Science, Toho University to TN.

\section{References}

Amor A (1971) Echiura from Brazil. Physis 30: 521-538.

Biseswar R (1988) Thalassema (Echiura) from southern Africa with the description of a new species. South African Journal of Zoology 23: 81-91.

Bleidorn C, Vogt L, Bartolomaeus T (2003) New insights into polychaete phylogeny (Annelida) inferred from 18S rDNA sequences. Molecular Phylogenetics and Evolution 29: 279-288. doi: 10.1016/S1055-7903(03)00107-6

Bock S (1942) On the structure and affinities of "Thalassema" lankesteri and the classification of the group Echiuroidea. Göteborgs Kungliga Vetenskaps- och Vitterhets-Samhälles Handlingar, Sjätte följden, ser. B 2(6): 1-94.

Chen Y, Yeh C-C (1958) Notes on some Gephyrea of China with description [sic] of four new species. Acta Zoologica Sinica 10: 265-278.

Edmonds SJ (1960) Some Australian echiuroids (Echiuroidea). Transactions of the Royal Society of South Australia 83: 89-98. http://biostor.org/reference/114392

Edmonds SJ (1987) Echiurans from Australia (Echiura). Records of the South Australian Museum 32: 119-138.

Fisher WK (1946) Echiuroid worms of the North Pacific Ocean. Proceedings of the United States National Museum 96: 215-292. http://si-pddr.si.edu/jspui/handle/10088/16451, doi: $10.5479 /$ si.00963801.96-3198.215

Fisher WK (1949) Additions to the echiuroid fauna of the North Pacific Ocean. Proceedings of the United States National Museum 99: 479-497. http://si-pddr.si.edu/jspui/handle/10088/16508, doi: 10.5479/si.00963801.99-3248.479

Ikeda I (1904) The Gephyrea of Japan. The Journal of the College of Science, Imperial University of Tokyo, Japan 20: 1-87. http://repository.dl.itc.u-tokyo.ac.jp/dspace/handle/2261/32786

Ikeda I (1924) Further notes on the gephyrea of Japan, with descriptions of some new species from the Marshall, Caroline and Palau Islands. Japanese Journal of Zoology 1: 23-44.

Ishikawa H (1938) Jikken Ouyou Tsuriesa-mushi Riyou no Kenkyu [Studies on the worms used for fish bait]. Tsuri-shiryou Kenkyukai [Association for fish bait studies], Fukuoka, $14+253 \mathrm{pp}$.

McHugh D (1997) Molecular evidence that echiurans and pogonophorans are derived annelids. Proceedings of the National Academy of Science, USA 94: 8006-8009. doi: 10.1073/ pnas.94.15.8006

Mori T, Tamura S, Makino K (1932) Hiroshima-ken San Syuyou Esa-mushi Rui ni Kansuru Chousa Houkokusyo [Research report on animals used for fish bait in Hiroshima Prefecture]. Hiroshima-ken Suisan Shiken-jo Houkoku [Bulletin of the Hiroshima Prefectural Fisheries Experimental Station] 1932: 1-45. 
Nishikawa T (1992) The Phylum Echiura. In: Nishimura S (Ed) Guide to Seashore Animals of Japan with Color Pictures and Keys, vol. 1. Hoikusha, Osaka, 306-309.

Nishikawa T (2001) New localities of the echiuran, Arhynchite arhynchite (Ikeda) and the enteropneust, Ptychodera flava Eschscholtz in the Japanese waters, revealed by a survey of specimens kept in the University Museum, University of Tokyo. The Nanki Seibutu 43: 137-138.

Nishikawa T (2004) Synonymy of the West-Pacific echiuran Listriolobus sorbillans (Echiura: Echiuridae), with taxonomic notes towards a generic revision. Species Diversity 9: 109123. http://ci.nii.ac.jp/naid/110006794426/en

Nishikawa T (2007) Yumushi-doubutsu Mon [Phylum Echiura]. In: Iijima A (Ed) Dai Nanakai Shizen-kankyo Hozen Kiso Chousa: Senkai-iki Seitaikei Chousa (Higata Chousa) Houkokusyo [The 7th National Survey on the Natural Environment: Shallow Sea Survey (Tidal Flats)]. Biodiversity Center of Japan, Nature Conservation Bureau, Ministry of the Environment, Fujiyoshida, 177-181.

Nishikawa T (2012) Thalassema owstoni Ikeda, 1904. In: Japanese Association of Benthology (Ed) Threatened Animals of Japanese Tidal Flats: Red Data Book of Seashore Benthos. Tokai University Press, Hatano, 237.

Saito H, Niwa N, Kawai K, Imabayashi H (2011) Current state of aquatic animals sold as sport fishing bait in Western Japan. Bulletin of the Hiroshima University Museum 3: 45-57.

Sato H (1934) On the sipunculids and echiurids of Onomichi Bay, Japan. Dobutsugaku Zasshi 46: 245-253. http://ci.nii.ac.jp/naid/110003359588

Sato H (1935) Fauna Nipponica, vol. VI, Class Echiuroidea, Class Sipunculoidea, Class Priapuloidea. Sanseido, Tokyo, $2+96$ pp.

Satô H (1937) Echiuroidea, Sipunculoidea and Priapuloidea obtained in Northeast Honshû, Japan. Saito Ho-on Kai Museum Research Bulletin 12: 137-176.

Satô H (1939) Studies on the Echiuroidea, Sipunculoidea and Priapuloidea of Japan. Science Reports of the Tohoku Imperial University, 4th ser., Biology 14: 339-460.

Saxena R (1984) Taxonomic review of genus Thalassema (Phylum Echiura). Uttar Pradesh Journal of Zoology 4: 77-82.

Stephen AC, Edmonds SJ (1972) The Phyla Sipuncula and Echiura. Trustees of the British Museum (Natural History), London, vii + 528 pp.

Struck TH, Schult N, Kusen T, Hickman E, Bleidorn C, McHugh D, Halanych KM (2007) Annelid phylogeny and the status of Sipuncula and Echiura. BMC Evolutionary Biology 7: 57. doi: 10.1186/1471-2148-7-57

Struck TH, Paul C, Hill N, Hartmann S, Hösel C, Kube M, Lieb B, Meyer A, Tiedemann R, Purschke G, Bleidorn C (2011) Phylogenomic analyses unravel annelid evolution. Nature 471: 95-98. doi: 10.1038/nature09864

Wharton LD (1913) A description of some Philippine thalassemae with a revision of the genus. The Philippine Journal of Science 8(D): 243-270. http://www.biodiversitylibrary. org/page/34797915\#page/307/mode/1up 